\begin{tabular}{l|c|c}
\hline ISSN: 0001-5113 & ACTA ADRIAT., & SHORT COMMUNICATION \\
AADRAY & $61(2): 211-216,2020$ & \\
\hline \hline
\end{tabular}

\title{
A new maximum length of the spotted weever, Trachinus araneus Cuvier, 1829 (Perciformes: Trachinidae) from Western Mediterranean (Oran Bay)
}

\author{
Lotfi BENSAHLA-TALET and Ahmed BENSAHLA-TALET \\ University Oran1. Ahmed BENBELLA, Faculty of Natural Science and Life, \\ Department of Biology, 31000-Oran, Algeria
}

*Corresponding author: bensahlatalet.lotfi@univ-oran1.dz

On the 29th of October 2018, one specimen of the spotted weever, Trachinus araneus measuring $47.3 \mathrm{~cm}$ in total length and weighting $968 \mathrm{~g}$ was captured by trammel net operating in Oran Bay (Kristel fishery) Western Algerian coast at $100 \mathrm{~m}$ depth. Up to date, this length is a new record of maximum length reached for this trachinid in the Mediterranean basin.

Key words: The spotted weever, Trachinus araneus, maximum size, Oran Bay, Mediterranean Sea

\section{INTRODUCTION}

The maximum observed length of individuals of certain fish species is a useful information for a rapid evaluation of growth rates in the absence of basic data (LEGENDRE \& ALBARET, 1991; FROESE and BINOHLAN, 2000; AKYOL et al., 2007). Maximum length and maximum weight are important theoretical parameters in fisheries science. Directly or indirectly, these measurements enter in most of the models used in stock assessments. In this sense, updating the maximum size of a species that might be commercially exploited in the future, gains importance (BORGES, 2001).

The spotted weever Trachinus araneus is a member of Trachinidae family found in the eastern Atlantic, from Morocco to southern Angola. Its range extends north into the Mediterranean, and along the Atlantic coast of Europe to southern Portugal (CARPENTER et al., 2015). It is particularly abundant in the eastern Mediterranean. It lives in the shallow waters on sandy and sandy-muddy detrital bottoms, up to about $100 \mathrm{~m}$ deep, burrowing into the substrate. It feeds on small fish and crustaceans (FROESE \& PAULY, 2018).

It is a venomous species that commonly reaches between 10 and $30 \mathrm{~cm}$ in total length, with a maximum of $45 \mathrm{~cm}$ in the Mediterranean and between 15 to $20 \mathrm{~cm}$ with a maximum of $36 \mathrm{~cm}$ in the Black Sea (BAUCHOT and HUREAU, 1986).

It appears to be both common and abundant, particularly in the eastern Mediterranean. This species is taken as bycatch in demersal trawl fisheries and is sometimes marketed. This species is likely found in marine protected areas throughout its range. Therefore, $T$. araneus is assessed as Least Concern (CARPENTER et al., 2015). 
Limited bibliography is available for T. araneus focusing mainly on envenomation (BEDINI et al., 2003; ERYILMAZ et al., 2006; SMITH and WHEELER,2006; PORTILLO STREMPEL, 2009; ALPARSLAN et al., 2010, YILDIZ and KARAKULAK, 2018) or heavy metal contents (CABRERA et al., 1994; LÓPEZ et al., 2000 and BRAMBILLA et al., 2013). Up to date, no studies were conducted on this trachinid in Algerian waters. The aim of this paper is to present the maximum total length of the spotted weever T. araneus documented up to now in the Mediterranean.

\section{MATERIAL AND METHODS}

On the $29^{\text {th }}$ of October 2018, one specimen of $T$. araneus (Fig. 1) measuring $47.3 \mathrm{~cm}$ in total length (TL) was captured by trammel net in Oran Bay (Kristel fishery) $\left(35^{\circ} 49^{\prime} 36.0^{\prime \prime} \mathrm{N}\right.$ $0^{\circ} 32^{\prime} 30.7^{\prime \prime} \mathrm{W}$ ), on sandy bottom at a depth of $100 \mathrm{~m}$ (Fig. 2). T. araneus specimen was measured to the nearest millimeter and weighted to the nearest $\mathrm{g}$ then photographed. For otoliths (Fig.3) measurements an electronic caliper (Digiroch) was used, unfortunately otoliths were too thick to be read directly under binocular microscope to determine the age of $T$. araneus specimen.

The specimen was identified using FAO species identification sheets (BAUCHOT and HUREAU, 1986; DJABALI et al., 1993) on the basis of the following morphological characters: the body elongated and compressed; very small eyes located

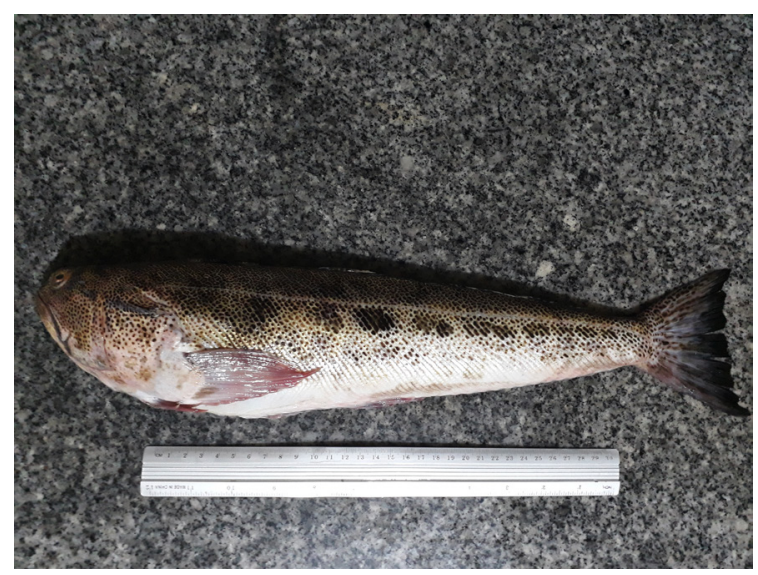

Fig. 1. Trachinus araneus ( $47.3 \mathrm{~cm}$ TL) caught in Oran Bay, (Photo: Lotfi BENSAHLA TALET) near the dorsal profile of the head; very oblique large mouth, with maxillary extending slightly beyond the posterior edge of the eye; villiform teeth; presence of 2 strong venomous spines on the operculum, 2 spines on the anterodorsal edge of the orbit and 6 dorsal spines in the first dorsal fin, the second dorsal fin contains 29 soft rays and the anal fin counts 27 ; the back and flanks yellowish gray, with 9 dorsal brownish to blackish spots and, beneath the lateral line, an alignment of large, more or less rounded or quadrangular spots; black dorsal fin; caudal fin lined with black and with some dark spots.

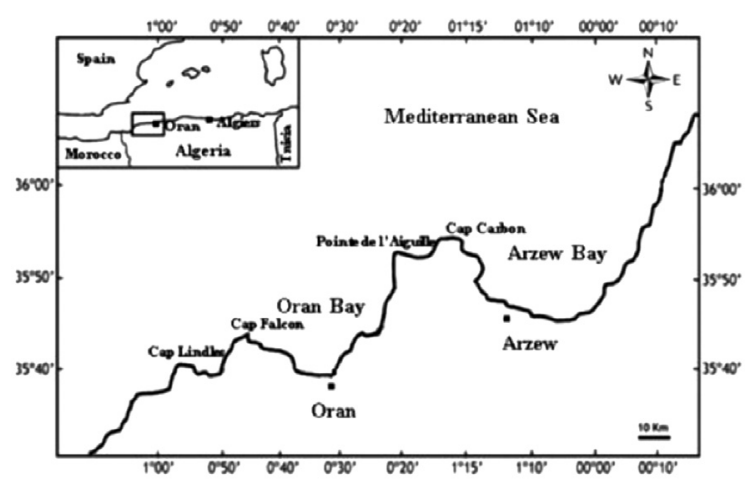

Fig. 2. Sampling location of spotted weever (Trachinus araneus) specimen

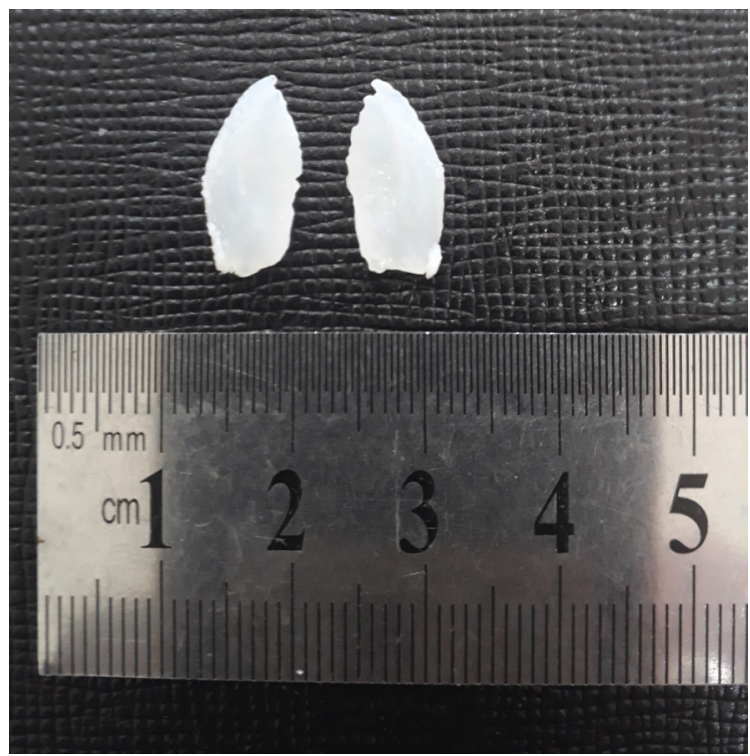

Fig. 3. Otoliths of T. araneus caught in Oran Bay 


\section{RESULTS AND DISCUSSION}

Measurements and percentage of each body part and otolith measurements are reported in relation to total length and are given in Table 1.

Table 1. Morphometric measurements as percentage of total length (\%TL) of Trachinus araneus caught in Oran Bay, Western Mediterranean Sea

\begin{tabular}{|c|c|c|}
\hline Morphometric characteristic & $\begin{array}{l}\text { Measurement } \\
(\mathrm{cm})\end{array}$ & $\begin{array}{c}\text { Pro- } \\
\text { portion } \\
(\%)\end{array}$ \\
\hline Total length (TL) & 47.283 & 100.00 \\
\hline Fork length (FL) & 45.837 & 96.94 \\
\hline Standard length (SL) & 41.21 & 87.16 \\
\hline Pectoral fin length (LP) & 6.992 & 14.79 \\
\hline Ventral fin length (LV) & 3.585 & 7.580 \\
\hline Pre-ventral fin distance (PVD) & 5.623 & 11.89 \\
\hline Cephalic length (LC) & 7.258 & 15.35 \\
\hline Post-orbital distance (PO1) & 5.859 & 12.39 \\
\hline Eye diameter $(\mathrm{O})$ & 0.705 & 1.490 \\
\hline Post-orbital distance (POD2) & 3.084 & 6.520 \\
\hline Pre-pectoral distance (PPD) & 9.861 & 20.86 \\
\hline Maxillary length (LM) & 2.722 & 5.760 \\
\hline Anal fin length (LA) & 27.08 & 57.27 \\
\hline Pre-anal fin distance (PAD) & 11.38 & 24.07 \\
\hline Minimum body height (TPC) & 2.650 & 5.600 \\
\hline Maximum body height $(\mathrm{T})$ & 9.080 & 19.20 \\
\hline Total weight $(\mathrm{TW}, \mathrm{g})$ & 0.968 & - \\
\hline Otoliths measurements & Right & Left \\
\hline Total length & 1.470 & 1.488 \\
\hline Wide & 0.727 & 0.743 \\
\hline Total weight $(\mathrm{g})$ & 0.338 & 0.345 \\
\hline
\end{tabular}

Comparing our findings to those of MOUTOPOULOS and STERGIOU (2002), fork length represented $95.13 \%$ from total length and standard length represented $87.33 \%$ of total length of $T$. araneus from Greek waters which is close to our results with fork length representing 96.94\% from total length and standard length representing $86.16 \%$ of total length. In an unpublished observation for the same species in Philippines, REYES in FROESE and PAULY, 2018 proportions of different body parts reported to total length were the same as our findings except two parameters,
Pre-ventral distance represented $15.3 \%$ while we found $11.89 \%$, and Head length represented $23.4 \%$ while we found only $15.35 \%$ for $T$. araneus caught in Oran Bay.

For Atlantic waters, maximum length recorded for T. araneus was $45 \mathrm{~cm}$ (SL) (ROUX, 1990 in QUÉRO et al., 1990), the same length (standard length) was assumed by CARPENTER et al., 2015. Central Mediterranean basin recorded a specimen in Greece (Table 2) measuring $39 \mathrm{~cm} \mathrm{TL}$ and weighting $490.75 \mathrm{~g}$ while in Turkey one specimen was caught measuring $31 \mathrm{~cm}$ and weighting 230g in 2006 (KARAKULAK et al., 2006). The maximum length ever recorded for Turkish and Mediterranean waters $(40.8 \mathrm{~cm}$ TL and weighting $758 \mathrm{~g}$ ) was reported by OZTEKIN et al., 2016.

Table 2. Maximum length records of Trachinus araneus given by several authors

\begin{tabular}{|l|l|l|l|}
\hline Location & $\begin{array}{l}\text { TL } \\
(\mathbf{c m})\end{array}$ & TW(g) & References \\
\hline $\begin{array}{l}\text { Aegean Sea } \\
\text { (Greece) }\end{array}$ & 39.0 & $490.75^{* *}$ & $\begin{array}{l}\text { MOUTOPOULOS } \\
\text { and STERGIOU, } \\
2002\end{array}$ \\
\hline $\begin{array}{l}\text { Aegean Sea } \\
\text { (Turkey) }\end{array}$ & 31.0 & 230.00 & $\begin{array}{l}\text { KARAKULAK et } \\
\text { al.,2006 }\end{array}$ \\
\hline $\begin{array}{l}\text { Gallipoli } \\
\text { peninsula, } \\
\text { Turkey }\end{array}$ & 40.8 & 758.00 & $\begin{array}{l}\text { OZTEKIN et al., } \\
\text { 2016 }\end{array}$ \\
\hline $\begin{array}{l}\text { North } \\
\text { Eastern } \\
\text { Atlantic }\end{array}$ & $40^{*}$ & - & $\begin{array}{l}\text { HUREAU et al., } \\
1979\end{array}$ \\
\hline $\begin{array}{l}\text { Eastern } \\
\text { tropical } \\
\text { Atlantic }\end{array}$ & $45^{*}$ & - & $\begin{array}{l}\text { ROUX, 1990 in } \\
\text { Quéro } \text { et al., 1990 }\end{array}$ \\
\hline Oran Bay & 47.3 & 968.00 & Present study \\
\hline
\end{tabular}

*Standard lenth $(S L) * *$ calculated from LWR (Length weight relationship)

\section{CONCLUSIONS}

The maximum size found for the spotted weever T. araneus $(47.3 \mathrm{~cm}, 968 \mathrm{~g})$ caught in Oran Bay can be considered as a new maximum length for this species in Algerian and Mediterranean waters. 


\section{ACKNOWLEDGEMENTS}

The author is very grateful to fishermen of Kristel Fishery and especially to Mr. Mokhtar. This paper is dedicated to the memory of Professor Ahmed BENSAHLA-TALET, my beloved father and mentor, who was an Algerian marine biologist. He worked more than 49 years and was dedicated to science. He was also Dean of Faculty of Natural sciences and life at University Oran 1 Ahmed BENBELLA (2012-2020). He passed away on $31^{\text {th }}$ July 2020 (December, $1^{\text {st }} 1946-$ July, $31^{\text {th }} 2020$ )

\section{REFERENCES}

AKYOL, O., H. ŞEN \& H. T. KINACIGIL. 2007. Reproductive biology of Eledone moschata (Cephalopoda: Octopodidae) in the Aegean Sea (Izmir Bay, Turkey). J. Mar. Biol. Assoc. UK, 87(4), 967-970.

ALPARSLAN, M., H. BARIS ÖZALP \& S. DOĞU. 2010."Poisonous Marine Organisms In Turkey And First Medical Aids." (2010): 616623.

BAUCHOT, M.-L. \& J.-C. HUREAU. 1986. Sparidae. p. 883-907. In P.J.P. Whitehead, M.-L. Bauchot, J.-C. Hureau, J. Nielsen and E. Tortonese (eds.) Fishes of the north-eastern Atlantic and the Mediterranean. volume 2. UNESCO, Paris, pp. 517-1007.

BEDINI, R., M.G. CANALI \& A. BEDINI. 2003. True and false threatening visual cues in some Mediterranean fish. J. Mar. Biol. Assoc. UK, 83(2), 265-270.

BORGES, L. 2001. A new maximum length for the snipefish Macroramphosus scolopax. Cybium, 25(2): 191-192.

BRAMBILLA, G., M.C. ABETE., G. BINATO., E. CHIARAVAlle., M. COSSU, E. DELlatTE \& A. UBALDI. 2013. Mercury occurrence in Italian seafood from the Mediterranean Sea and possible intake scenarios of the Italian coastal population. Regul. Toxicol. Pharmacol, 65(2), 269-277.

CABRERA, C, M.L. LORENZO, C. GALLEGO, M.C. LOPEZ \& E. LILLO. 1994. Cadmium contamination levels in seafood determined by electro- thermal atomic absorption spectrometry after microwave dissolution. J. Agri. Food. Chem, 42(1), 126-128.

CARPENTER, K.E., W.F. SMITH-VANIZ., G. DE BRUYNE \& L. de MORAIS. 2015. Trachinus araneus. TheIUCNRedListofThreatenedS pecies.2015:e.T198718A42691939.http:// dx.doi.org/10.2305/IUCN.UK.20154.RLTS. T198718A2691939.en

CUVIER, G \& A. VALENCIENNES. 1829. Suite du Livre troisième. Des percoïdes à dorsale unique à sept rayons branchiaux et à dents en velours ou en cardes. Tome troisième. i-xxviii, [1-2], 1-500, pls. 41-71. Eds.F.G. Levrault Paris (Avril 1829).

ERYILMAZ, M., M. DURUSU., M. Ö MENTEŞ., T. YIĞIT., N ZEYBEK \& K. ÖNER. 2006. Envenomation caused by weever fish. Turk. J. Emer. Med, 6(3), 142-145.

FROESE, R \& C. BINOHLAN. 2000. Empirical relationships to estimate asymptotic length, length at first maturity, and length at maximum yield per recruit in fishes, with a simple method to evaluate length frequency data. J. Fish. Biol, 56(4): 758-773.

FROESE, R \& D. PAULY. 2018. FishBase. World Wide Web electronic publication. www.fishbase.org, version (10/2017) (accessed date: 01 November. 2018).

HUREAU, J.-C. \& T. MONOD (Editors), 1979. Checklist of the fishes of the north-eastern Atlantic and of the Mediterranean (CLOFNAM I and II). United Nations Educational Scientific and Cultural Organization (UNESCO), Paris, France. Vols 1-2. 683 p.

LEGENDRE, M \& J.J. ALBARET. 1991. Maximum observed length as an indicator of growth rate in tropical fishes. Aquacult., 94: 327341.

LÓPEZ, F. F., C. CABRERA., M. LORENZO \& M.C. LÓPEZ. 2000. Aluminum content in foods and beverages consumed in the Spanish diet. J. Food. Sci, 65(2), 206-210.

MOUTOPOULOS, D.K \& K.I. STERGIOU. 2002. Length-weight and length-length relationships of fish species of the Aegean Sea (Greece). J. Appl. Ichthyol. 18(3):200-203.

PORTILLO STREMPEL, A., E. CEBALLOS HERRERA 
\& J. PORTILlO STREMPEL. 2009. Poisonous fish stings on the coast of Malaga, Spain: summertime incidence $=$ Incidencia de picaduras de peces venenosos en la costa de Málaga, España, durante la época estival. Emergencias, (1).

QUÉRO, J.-C., J.-C. HUREAU, C. KARRER, A. POST \& L. SALDANHA (Editors), 1990. Check-list of the fishes of the eastern tropical Atlantic (CLOFETA). JNICT (Lisbon), EIU (Paris) and UNESCO (Paris),.pp. xxxii+1492.

ROUX, C. 1990. Trachinidae. p. 893-895. In J.C. Quero, J.C. Hureau, C. Karrer, A. Post and L.
Saldanha (Editors). Check-list of the fishes of the eastern tropical Atlantic (CLOFETA). JNICT, Lisbon; SEI, Paris; and UNESCO, Paris. Vol. 2., pp. xxxii+1492.

SMITH, W. L \& W.C. WHEELER .2006. Venom evolution widespread in fishes: a phylogenetic road map for the bioprospecting of piscine venoms. J. Hered, 97(3), 206-217.

YILDIZ, T. \& F.S. KARAKULAK. 2018. Türkiye'nin Zehirli Balıklarından Trakonya Balığının Toksik Etkileri. Aquat. Sci. Eng, 33(1), 20-24.

Received: 15 November 2019

Accepted: 22 August 2020 
Nova maksimalna dužina pauka crnca, Trachinus araneus Cuvier, 1829 (Perciformes: Trachinidae) iz zapadnog Mediterana, zaljev Oran

\author{
Lotfi BENSAHLA-TALET i Ahmed BENSAHLA-TALET
}

\title{
SAŽETAK
}

Dana 29. listopada 2018. g. ulovljen je jedan primjerak pauka crnca, Trachinus araneus Cuvier, čija je totalna dužina iznosila 47,3 cm, a masa 968 grama. Primjerak je ulovljen na dubini od $100 \mathrm{~m}$ u zaljevu Oran (zapadna alžirska obala).

Ovo je dosada najveća zabilježena dužina za ovu vrstu u mediteranskom bazenu.

Ključne riječi: pauk crnac, Trachinus araneus Cuvier, maksimalna veličina, zaljev Oran, Sredozemno more 